D) Check for updates

Cite this as: $B M J 2020 ; 369: m 2407$ http://dx.doi.org/10.1136/bmi.m2407 Published: 18 June 2020

\section{Has Sweden's controversial covid-19 strategy been successful?}

This feature article by Heba Habib (BMJ

2020;369:m2376, doi:, published 12 June 2020) stated that schools in Sweden were closed to children under

16. It should have said that schools were closed to children over 16. 